\title{
Is the butterfly Tomares ballus (Lepidoptera: Lycaenidae) a potential pest of Lens culinaris (Leguminosae)?
}

\author{
José Martín Cano, Pilar Gurrea, Blanca Montalbán, Leticia Ureña \& Javier Iglesias \\ Laboratorio de Entomología. Departamento de Biología, C./ Darwin, 2, Universidad Autónoma de Madrid, Campus \\ de Cantoblanco, ES 28049 Madrid, España; jose.martin.cano@uam.es; pilar.gurrea@uam.es; \\ ciber_blanca@hotmail.com; leticia_uf84@hotmail.com; dr_paramecio2@yahoo.es
}

Received 16-V-2008. Corrected 18-XI-2008. Accepted 16-XII-2008.

\begin{abstract}
The lentil (Lens culinaris) is identified as a new host plant of the lepidopteran Tomares ballus. Five larvae of T. ballus were found on 19 May, 2007 in a crop of "castellana" lentils in Toledo Province, Spain and reared in the laboratory. The larval brown spiracles are slightly darker than the rest of the pupa. Traditional cultural practices reduce the insect's probability of completing its life-cycle. We present flight phenology data for T. ballus from the unedited Atlamar database (1 073 records from 1887 to 2003), based on the 438 records for which the year, month and day are known. This period coincides with the flowering and formation of the legumes of various species of leguminosae, such as lentils. The peak activity of the imagos occurs in the second half of March and the first half of April, and the last larvae must be present in the field until the beginning of June. Rev. Biol. Trop. 57 (3): 623-634. Epub 2009 September 30.
\end{abstract}

Key words: Tomares ballus, Lycaenidae, lentil, host plant, pest, Lens culinaris.

Tomares ballus (Fabricius, 1787) is a species of butterfly of the Lycaenidae family that occurs in the western Mediterranean. In Africa it is found in the north of Morocco, Algeria and Tunisia, and in Europe in Portugal, Spain and the French Mediterranean (Tolman and Lewington 2002).

It has a wide distribution within the Iberian Peninsula that approximately coincides with the area with a Mediterranean climate (GarcíaBarros et al. 2004). It is a univoltine species with pupal diapause. It is one of the earliestappearing butterflies since it is known to fly at the end of winter and beginning of spring. During the larval phase it feeds on a range of leguminous plants, depending on the areas (Tolman and Lewington 2002).

The caterpillars of $T$. ballus, like those of other Lycaenidae, seem to have a strong preference for feeding on flowers and fruits, which are the parts of plants that are especially rich in proteins. In most legume species that comprise its feeding spectrum, the caterpillars have to feed ectophytically, but in the case of Erophaca baetica the larvae of $T$. ballus are endophytic. This host plant is probably the most widely used in areas with a limy substrate throughout their distribution. According to Jordano (1987), Jordano et al. (1989) and Jordano et al. (1990), the female T. ballus deposits her eggs individually in the immature legume of E. baetica. The neonate penetrates the pod, feeds on the developing seeds and only emerges into the exterior when fully developed, whereupon it pupates on the ground. It is difficult to detect the caterpillar from the outside when it is feeding inside the legume. As the aforementioned authors have pointed out, this type of biology and feeding imply a high degree of synchronization between the phenologies of the plant and the lycaenid.

Specifically in the case of this host plant, E. boetica, the same authors have shown that 
the attack on a stand of these plants by larvae of the butterfly $T$. ballus causes a significant drop of up to $81.23 \%$ in the quantity of seeds produced (Jordano 1987, Jordano et al. 1990).

The larvae of $T$. ballus, like those of other lycaenids, possess myrmecophilous organs (Downey 1987). In this species in particular, the caterpillars have tentacular organs, Newcomer gland and glands in perforated cupolas. The tentacular organs and the Newcomer gland of T. ballus were described by Powell (1904). This information is quoted in compilations by various authors, including Malicky (1969, 1970) and Martín Cano (1981). However, in more recent publications concerning the morphology of the preimaginal stages, such as those of Jordano (1987) and Lockwood (2006), the presence of these structures is not explicitly confirmed; mention of them is by reference to the work of the aforementioned authors.

With respect to their relationship with ants, the caterpillars of this species may all be categorised as facultative myrmecophiles. If the appropriate species of ants are found in same places where the caterpillars live then symbiosis occurs; if not, the caterpillars develop adequately in their absence (Jordano 1987, Jordano et al. 1989). Nevertheless, Tolman and Lewington (1999) raised the possibility that pupation frequently occurs within ants' nests. This seems to be an unproven claim, arising mainly from the difficulty of finding pupae in the field.

Undoubtedly, the biology of T. ballus is little known; Lockwood (2006) has described how little information is available concerning their biology and ecology.

At the same time, it appears that in recent years there has been a substantial decrease in the number of populations of this butterfly, prompting Van Swaay and Warren (1999) to consider it to be a vulnerable (VU) species in Europe.

On the other hand, lentil (Lens culinaris) is a plant native to Asia, and it is an extremely important grain legume in the Near East and India. Widely cultivated in temperate and subtropical climates and in the tropics at high altitudes, with considerable extension as a crop in the Mediterranean basin and in many countries in Asia, Africa and America (Mexico, Peru, Argentina). The seeds are used mostly for human consumption, and the harvested vines for cattle feed (FAO 2008).

It does not occur spontaneously in Spain, nor does it usually become naturalized, although other species of the Lens genus are present in the Iberian peninsula (Castroviejo and Pascual 1997). In Spain, this crop still occupies considerable areas, principally in Castilla-La Mancha and Castilla y León (Castroviejo 2000). Currently, the cultivation of lentils is on the increase as a result of society's awareness of the problems arising from environmental change. According to the FAO (2003), the diverse strands of organic farming, such as the cropping methodologies known as Conservation Agriculture or Minimum Tillage, are becoming more common. These techniques are characterised by their slight impact on the land, the ploughing of the soil in a nontraditional manner, and minimal inputs of fuel, fertilizer and pesticide. The lentil occupies an important place among the crops that are most frequently grown under this agricultural system.

The aim of this paper is to identify this legume as a new host plant for T. ballus, to assess its ecological and economic impact and to present some new data on the biology and morphology of the preimaginal stages of this lycaenid that could be of use for its identification.

\section{MATERIAL AND METHODS}

Five larvae of $T$. ballus were found on 19 May, 2007 in a crop of lentils, Lens culinaris, in the town of Yepes, Toledo Province (39 $54^{\prime}$ '58' $\mathrm{N}, 03^{\circ} 38^{`} 01^{\prime}$ W, $697 \mathrm{~m}$ in elevation) during the systematic sampling of the ecosystems and agrosystems of the area using an entomological net. It is an unirrigated agricultural area with small plots of olive trees, vines, lentils, cereals, fallow land, etc. In the steepest parts remains of the natural vegetation persist. This consists of holm oak woodland (Quercus ilex 
subsp. ballota) with Kermes oak (Quercus coccifera), which are subjected to intense grazing by sheep.

The lentils were of the commercial variety "castellana". The cultivation is of the type traditional to the area: plants are sown in November or February, and harvesting is carried out in the second half of June.

The larvae collected were taken to the laboratory in the Zoology Department of the Universidad Autónoma de Madrid, where they were placed on Petri dishes and fed on fresh lentil plants of the same culture; the provision of flowers and tender legumes was maintained until they had fully developed. The light and temperature conditions were those of the laboratory, approximately $22^{\circ} \mathrm{C}$ and a $16: 8$ hour light:dark photoperiod.

In compiling the table of the larvae's host plants, the scientific names have been brought up to date taking into account the taxonomic and nomenclatural criteria of the Flora Iberica (Castroviejo 1999, 2000).

The flight phenology data for $T$. ballus have been extracted from the inedited Atlamar database, which was compiled for the production of the Atlas of the butterflies of the Iberian Peninsula and Balearic Islands (Lepidoptera: Papilionoidea \& Hesperioidea) (García-Barros et al. 2004). This database contains 292435 records and bring together practically all the published data on Iberian butterflies. It also compiles the data from the collections of the National Museum of National History in Madrid and of the Universidad Autónoma de Madrid, and also unpublished data from the authors and collaborators.

In the particular case of T. ballus, the database features 1073 records dating from 1887 to 2003 . To produce the flight phenology only the 438 records for which the year, month and day of observation of the specimens are known have been considered. These records mention more than 735 individuals, of which the sex of 365 males and 162 females could be determined.

\section{RESULTS}

Morphology and behaviour of the caterpillar and pupa: In the laboratory the caterpillars continued to develop and between 8 and 14 days later pupated inside the Petri dishes.

The lengths of the oldest larvae collected ranged between 12 and $15 \mathrm{~mm}$; the colour of the cephalic capsule at this age is light brown (Figure 1). Larval morphology, like the pattern and colouration, are typical of this family of

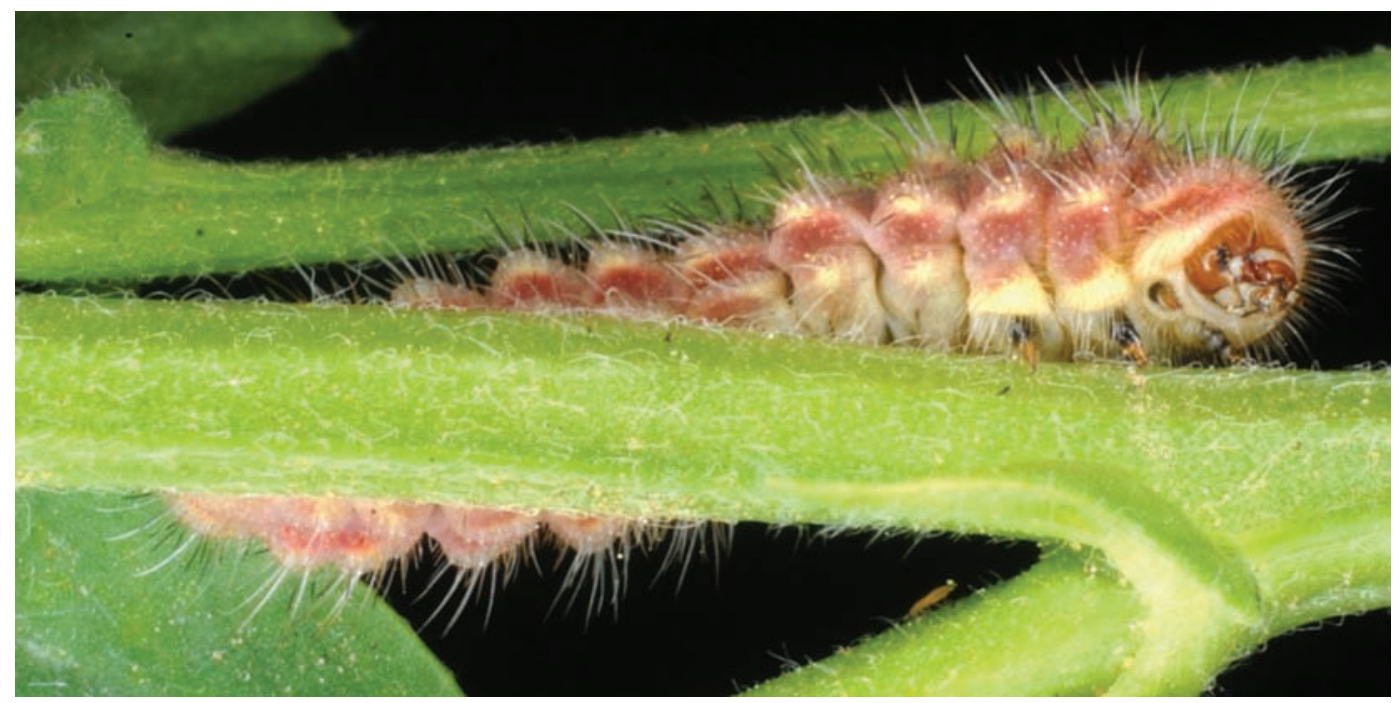

Fig. 1. Final stage larva of T. ballus with brown head. 
Lepidoptera. We draw attention to the fact that it has been possible to observe two different colouration patterns. Some caterpillars were lightcoloured, predominantly yellowish (Figure 2), while others were reddish (Figure 3). These colours remained practically unaltered throughout development in the laboratory.

Tentacles and Newcomer gland, the myrmecophilous structures characteristic of the lycaenid larvae could be seen in the caterpillars. Figure 7 shows the orifices opening to the exterior corresponding to these two structures. In the middle of the $7^{\text {th }}$ abdominal segment, the transverse slit corresponding to the orifice of the opening of the Newcomer glandular complex may be seen. In the adjacent $8^{\text {th }}$ abdominal segment, just behind the last pair of respiratory stigma, the circular exit orifices for the tentacular pairs, which are off-white in colour, are visible.

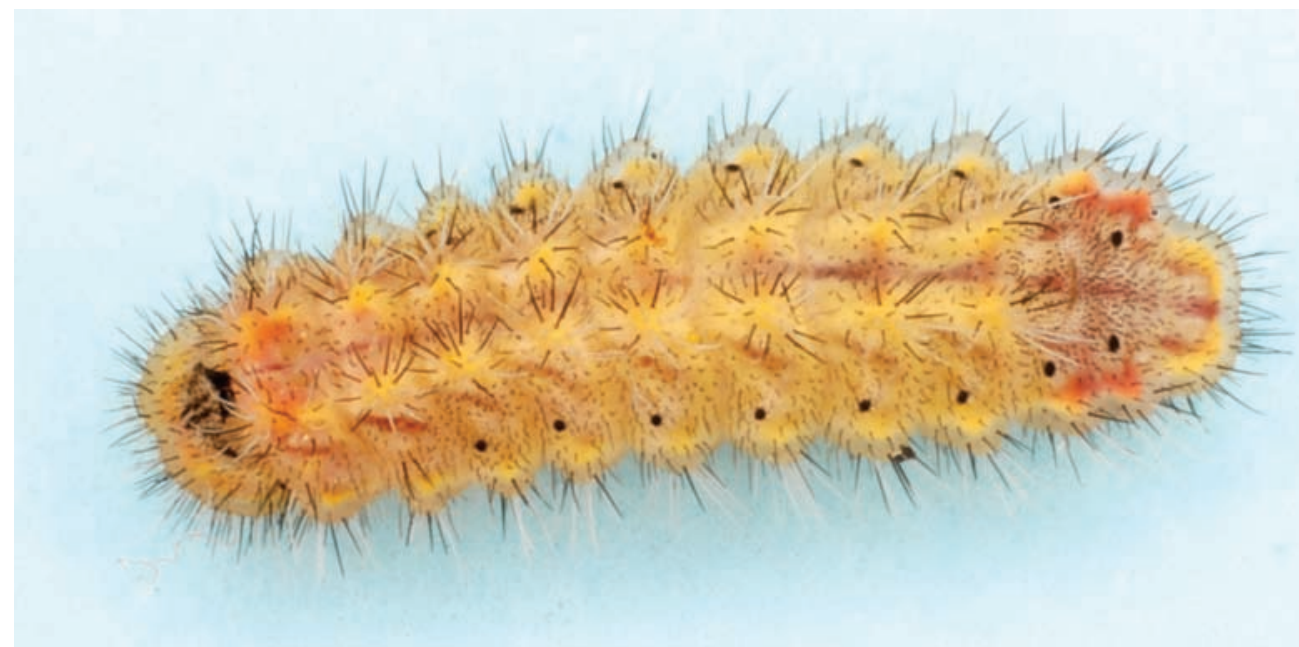

Fig. 2. Final stage larva of T. ballus with predominanly yellowish colours.

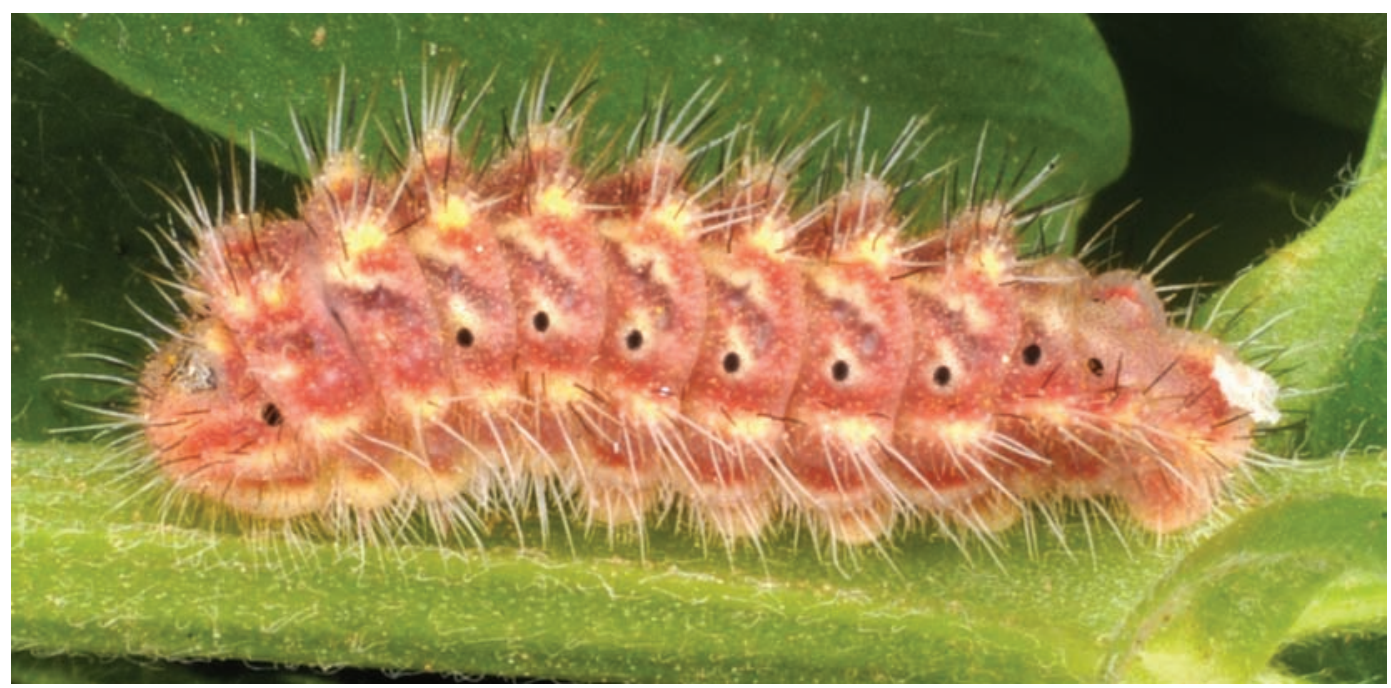

Fig. 3. Final satage larva of T. ballus with predominantly reddish colours. 
The pupa, which is about $9.7 \mathrm{~mm}$ long, is quite hard or leathery compared to other lycaenids. It is very dark and uniform, with no spots (Figures 4, 5 and 6). The entire surface is practically smooth, lacking a cremaster, and presents a small, wart-like pattern (Figure 8). In the laboratory the caterpillars ate the flowers of the plants and, preferentially, the green legumes. The trophic behaviour in the case of the flowers was completely ectophytic, at least in the final larval stage. However, feeding was partially endophytic when feeding on green seeds; the immature seeds were eaten through a hole in the pod into which the larva introduced its head and first thoracic segments (Figure 9).

Flight period of imagos: The flight period of the imagos of $T$. ballus according to the data extracted from the Atlamar database (GarcíaBarros et al. 2004) is shown in Figure 10. This period coincides with the flowering and formation of the legumes of various species of leguminosae, such as lentils. The peak activity of the imagos occurs in the second half of March and the first half of April, and the last larvae must be present in the field until the end of May or beginning of June.

\section{DISCUSSION}

Larval morphology: The descriptions and figures of the preimaginal stages of $T$. ballus that appear in the bibliography are very limited. Gómez de Aizpurua (1981) presented several photographs of caterpillars in different positions with some accompanying morphological details. Lockwood's (2006) publication cited another two photographs by R. Vila concerning final stage larva in dorsal and lateral views. These show well the general colouring of the larva, which is similar to that of the caterpillar in Figure 3, but these authors did not report the presence of red final-stage caterpillars, as we have observed (Figure 2), and as is similar to Lafranchis's (2002) very simplified scheme of the $T$. ballus caterpillar.

Other details can be made out in the photographs of Gómez de Aizpurua (1981) and R.
Vila (in Lockwood 2007) that are common to the yellowish and reddish caterpillars, such as the pattern of oblique lines on the lateral part of the segments, and the stigma with the edge emphasised in black. The marked pilosity and dark prothoracic plate are also noticeable. On the other hand, neither R. Vila's nor Gómez de Aizpurua's images show the exit orifices of the tentacles and the Newcomer gland, although, as mentioned above, these myrmecophilous structures had previously been identified in this species by Powell (1904).

Descimon and Nel (1986) and Tolman and Lewington (2002) concur with our observations concerning the behaviour of the caterpillars in the laboratory, that they remained very active, moving very quickly compared with the larvae of other lycaenids. The way in which the samples were collected in this study (by placing a net over the plants) did not allow us to determine the possible myrmecophilous relationships of this species, but we can state that they developed without apparent problems in the laboratory in the absence of ants and, contrary to what Tolman and Lewington (1999) suggest, they did not have any particular difficulty pupating under these conditions. In the same way as described by Jordano (1987), it was possible to observe in the laboratory that the prepupal period is quite long, with a duration of several days in which the caterpillars did not feed and moved rapidly, apparently seeking a suitable place to pupate. From our observations it may be deduced that pupation in the natural environment must occur on the ground, as also reported by Jordano (1987), although the possibility cannot be ruled out that part of the population achieves this inside ants' nests, as described by Tolman and Lewington (1999). Pupation probably takes place in locations well away from the host plant, which may explain the absence in the literature examined of any reference to observations of pupae in the natural environment.

The pupae are, logically, very similar to those drawn by Jordano (1987), and they appear darker than that in the photograph by Gómez de Aizpurua (1981), who reported that 

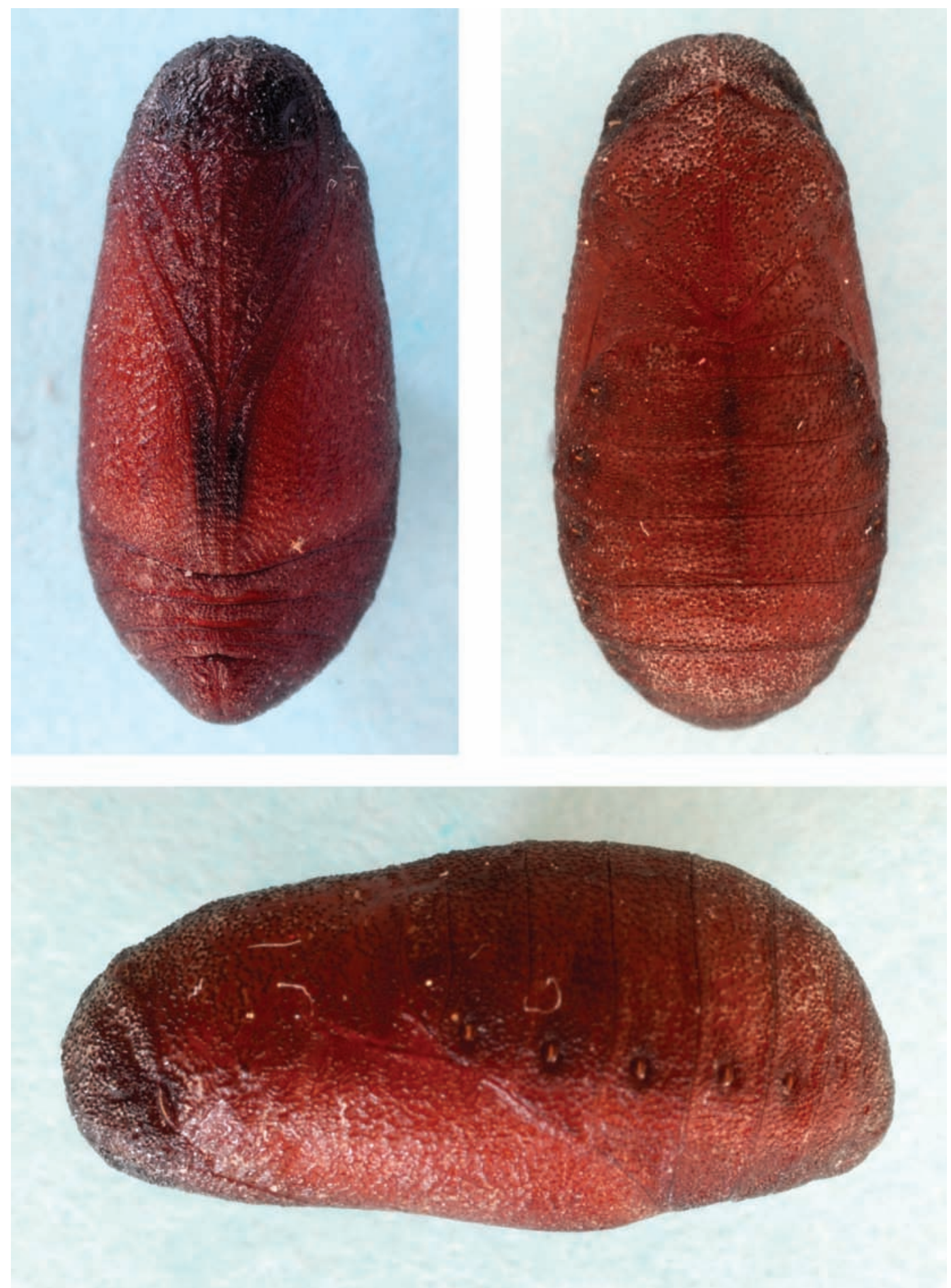

Figs. 4, 5, 6. Pupa of T. ballus. 


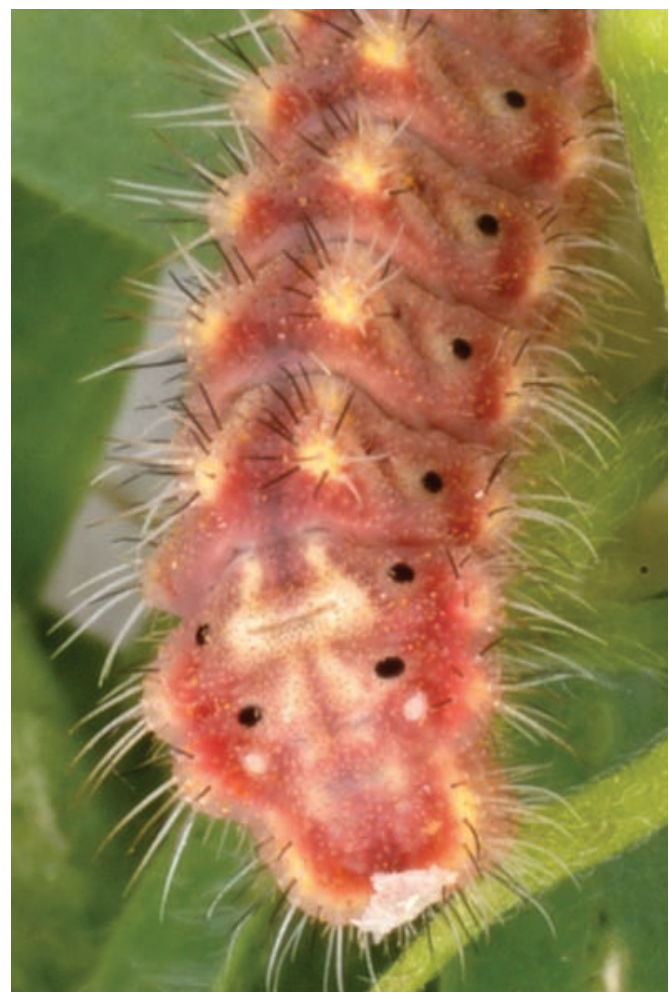

Fig. 7. Detail of the posterior segments of the larva of $T$. ballus showing the myrmecophilus organs.

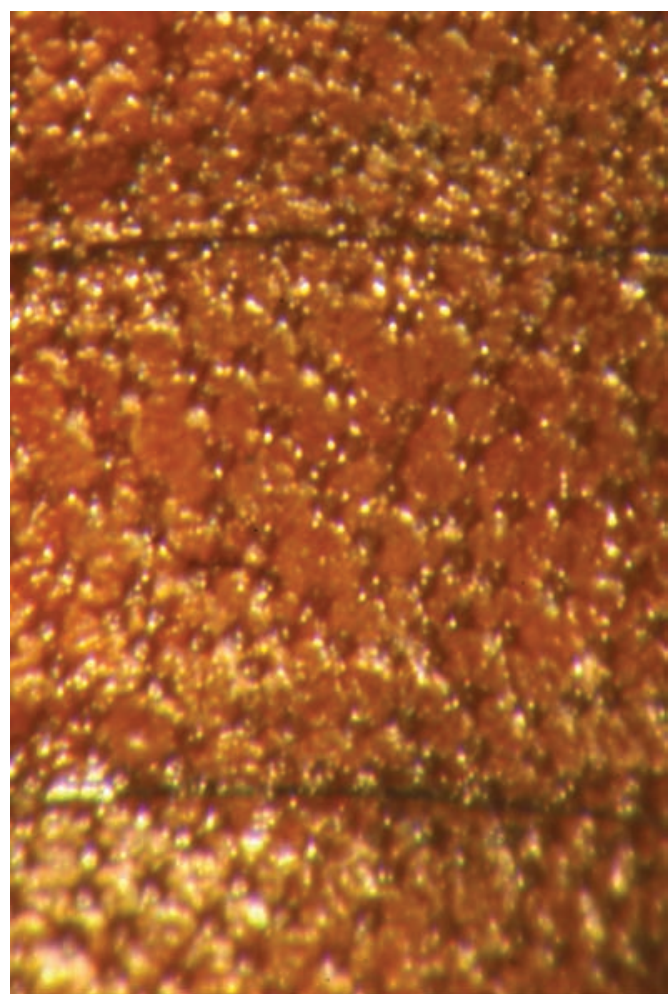

Fig. 8. Tegument of the T. ballus pupa showing the warts that give rise to the cuticular pattern.

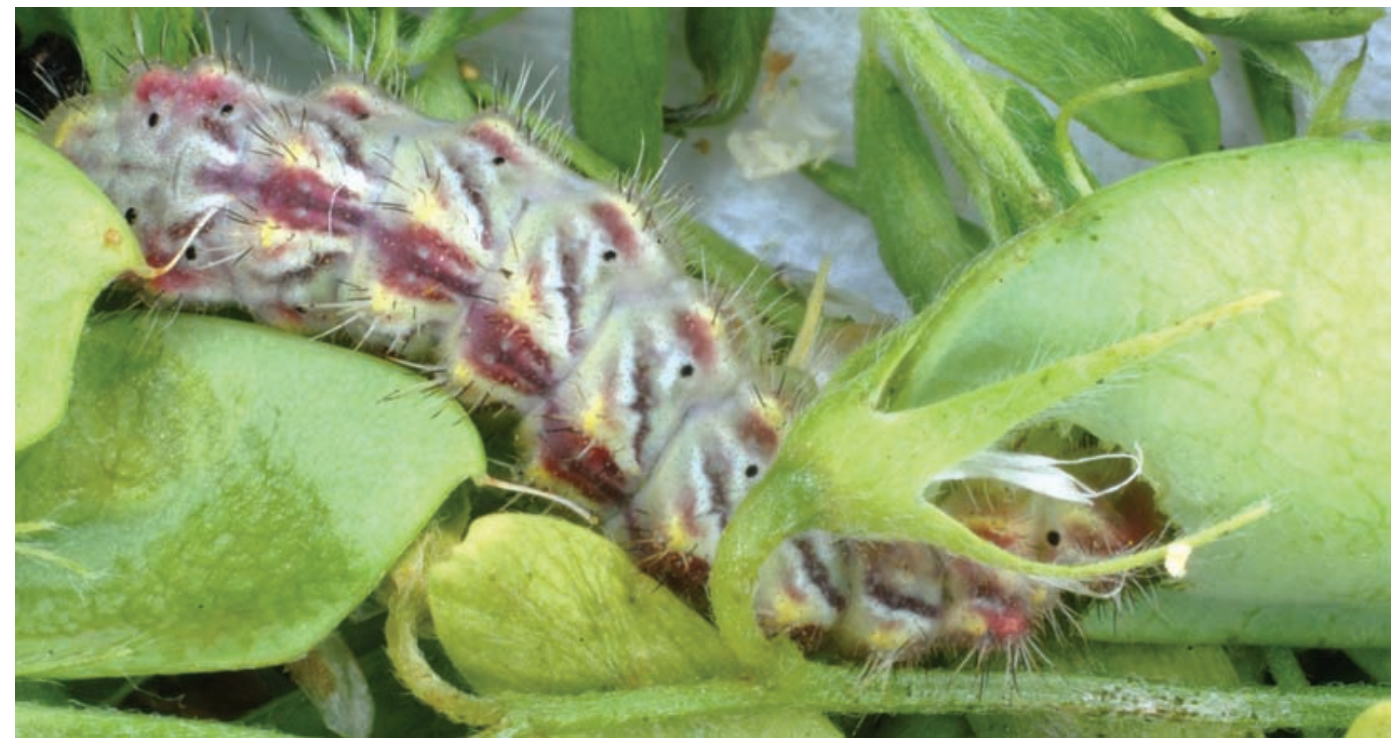

Fig. 9. Final stage larva of $T$. ballus feeding on a lentil legume. 


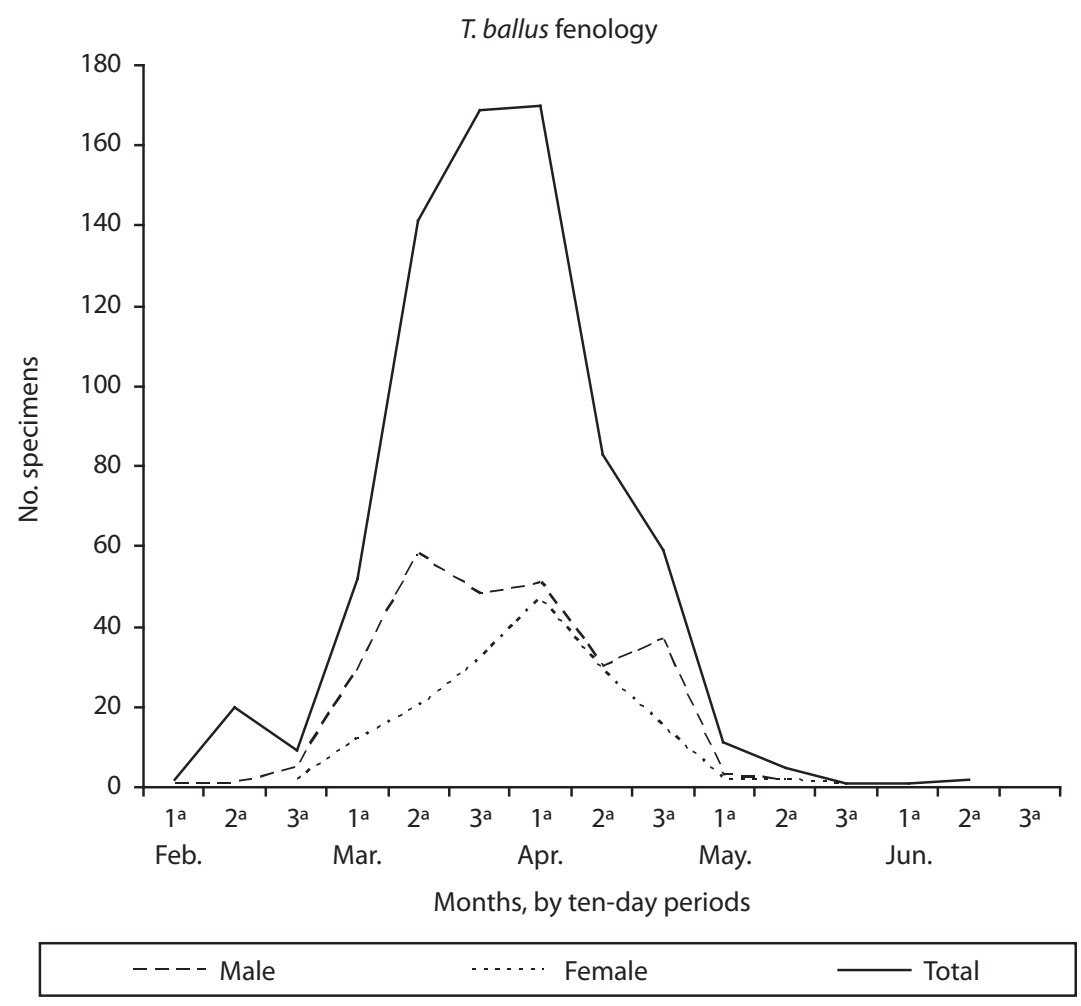

Fig. 10. Flight phenology of T. ballus by months (in ten-day periods), based on data from Atlamar (García-Barros et al. 2004).

the spiracles are orange in colour. We did not observe this; rather, we found the spiracles to be slightly darker brown than the rest of the pupa, as can been seen in the photographs.

Larval host plants: The larva of T. ballus has been reported to feed on several species of the Leguminosae family. These species belong to various genera that in their turn belong to a number of tribes of the subfamily Papilionoidea, as summarised in Table 1.

In the review undertaken here, we have not cited the lentil as one of the host plants. Neither have we described this species of lepidopteran as a pest of the lentil, as was suggested in studies such as that of Pérez Anduela et al. (2004).

The most widespread host plant appears to be Erophaca baetica. This is not thought to be palatable to many animals, which implies that the caterpillars of T. ballus must be able to neutralise the toxic substances present in this plant.

As we have mentioned, Jordano (1987), Jordano et al. (1989) and Jordano et al. (1990) reported that the larvae of $T$. ballus are endophytes when they feed on E. baetica. However, the size of the flowers and legumes of the host plants and the observations themselves in the case of Trifolium cheileri, indicate that feeding must most commonly be ectophytic. With the lentil, feeding behaviour is intermediate: the final stage caterpillar introduces its head and first segments inside the legume, but the final segments remain outside. This suggests a certain plasticity in the feeding habits of the larvae of this species, as is known in other lycaenids, 
TABLE 1

Host plants of the T. ballus larvae

\begin{tabular}{|c|c|c|c|c|}
\hline \multirow{2}{*}{$\begin{array}{l}\text { Family } \\
\text { Leguminosae } \\
\text { Subfamily } \\
\text { Papilionoidea }\end{array}$} & \multirow[b]{2}{*}{ Plant species } & \multicolumn{3}{|c|}{ Geographical areas } \\
\hline & & $\begin{array}{l}\text { Iberian } \\
\text { Peninsula }\end{array}$ & $\begin{array}{l}\text { South of } \\
\text { France }\end{array}$ & $\begin{array}{l}\text { North } \\
\text { Africa }\end{array}$ \\
\hline Tribe Astragaleae & $\begin{array}{l}\text { Erophaca baetica } \\
\text { Lens culinaris }\end{array}$ & $\begin{array}{c}4,5,6,7,10,12 \\
\text { new }\end{array}$ & & 2,13 \\
\hline Tribe Trifolieae & $\begin{array}{l}\text { Trifolium cherleri } \\
\text { Medicago lupulina } \\
\text { M. minima } \\
\text { M. polymorpha } \\
\text { M. littoralis } \\
\text { M. trunculatula } \\
\text { M. turbinate }\end{array}$ & $\begin{array}{c}4,6,5,7,10,12 \\
12 \\
5,6,10,12 \\
12 \\
12\end{array}$ & $\begin{array}{c}12 \\
8,11 \\
12\end{array}$ & 13 \\
\hline Tribe Loteae & $\begin{array}{l}\text { Lotus ornithopodioides } \\
\text { L. hispidus } \\
\text { Dorycnium hirsutum } \\
\text { D. pentaphyllum } \\
\text { Anthyllis tetraphylla } \\
\text { Ornithopus compressus }\end{array}$ & $\begin{array}{c}2,9,12 \\
9 \\
5,6,10,12\end{array}$ & $\begin{array}{c}8,11 \\
1 \\
2,8,11 \\
2 \\
1,2,8\end{array}$ & $\begin{array}{c}12 \\
2,13 \\
12\end{array}$ \\
\hline Tribe Coronilleae & Hippocrepis biflora & & 8,11 & \\
\hline Tribe Hedysareae & Onobrychis caput-galli & & 8,11 & \\
\hline
\end{tabular}

such as Lampides boeticus (Linnaeus, 1767), which feeds endophytically on the legumes of Colutea spp. and the pea (Pisum sativum), and ectophytically on other species of legumes such as alfalfa, Medicago sativa (Martín Cano 1979).

Assessment of the possible incidence of T. ballus as a pest of lentils: The main interest in Lens culinaris (lentil) as a new host plant of T. ballus is based on the fact that it is a cultivated plant. This confers a new significance on this lepidopteran in the field of applied entomology since it has previously only been found in wild legumes.

The biology of $T$. ballus has features in common with L. boeticus, which also feeds on legumes, and this raises the possibility that T. ballus is a potential pest. L. boeticus is the only lycaenid included in the Regulated Plant
Pest List, of the United States Department of Agriculture (USDA 2008), but we think the possibility that $T$. ballus may become a pest of lentils is worth further consideration.

If it has passed unnoticed until now, this is due to at least two factors other than just the species' low population density. First, the caterpillars are cryptic and therefore very difficult to see on the plant, and second, they finish their development before the lentils are harvested. The final larvae must drop to the ground in order to pupate at the beginning of June, while the crop is harvested in mid- or late June. If changes arose in the environmental conditions by which the biological cycle of the insect were delayed, or that of the plant were brought forward, these dynamics would be affected and the insect might be observed on the plant.

Pupation takes place on the ground in such a way that, especially in the seeds, no signs of 
their presence are found at the time of harvest. The traditional cultivation techniques of the lentil are an obstacle to T. ballus becoming a pest. This butterfly has a long period of hibernation, spending about ten months in the pupal phase. The pupation site is the ground and, as some authors have suggested, for part of the population, within ants' nests. In any case, the pupae remain on the ground for part of the summer, and throughout autumn and winter, until spring, when the imagos emerge. The lentil is an annual plant and is grown under a repeated annual cropping regime, or in rotation with cereals or sometimes a fallow period. The ground is ploughed after the lentils are harvested in readiness for the next crop. This can be done shortly after the harvest, later in the autumn or even at the end of winter, but always before the emergence of the imagos. This means that the majority of the pupae are destroyed or that at least imaginal emergence is made impossible by the burial of the chrysalids.

With the methodologies of Conservation Agriculture or Minimum Tillage, in which there is only slight intervention on the land, and the soil is not ploughed in the traditional manner, there could be some risk of T. ballus having an economic impact on the crop, since these types of cultivation may enable greater survival of pupae.

The cultivation techniques of Conservation Agriculture, which is becoming more common throughout the world (FAO 2003), could give rise to a problem, although, as in more fragmented areas of cultivation with fewer interventions, lentils tends to yield better balanced and self-regulated stands than in the large areas of monoculture where traditional methods are used (Pérez Anduela et al. 2002).

In summary, we may consider T. ballus not to be a potential pest of lentil crops at present, at least when grown using traditional practices. In fact, the crops may be more of an obstacle to the survival of this species of butterfly than to the expansion of its distribution, since they cause the waste of some of the populations' resources, considered in the form of eggs.
Under these circumstances, despite developing up to the pupal phase, they have a very low probability of completing their life-cycle. These decreased numbers may be important in this species, whose populations do not appear to be very abundant. Indeed, Van Swaay and Warren (1999) pointed out that they have experienced a drop in numbers of $20-50 \%$ in Europe in recent years, leading them to classify this species in the VU (vulnerable) category, as mentioned above.

\section{ACKNOWLEDGMENTS}

Phil Mason for reviewing drafts of this work. The information about the lentil varieties and the phenology of the crop was provided to us by M. de los Mozos from the Centro de Investigación Agraria de Albaladejito (Albaladejito Centre for Agrarian Research). This study was funded by Lafarge Cementos, as part of the scientific assessment work of the project Follow-up of the restoration of the quarry of Lafarge Asland in Yepes-Ciruelos.

\section{RESUMEN}

La lenteja (Lens culinaris) es una nueva planta hospedera de la mariposa Tomares ballus. Hallamos cinco larvas el 19 de mayo de 2007 en un cultivo de lentejas de la variedad "castellana" en la provincia de Toledo, España y las criamos en el laboratorio. Los espiráculos, de color marrón, son ligeramente más oscuros que el resto de la pupa. Las prácticas culturales tradicionales reducen al insecto la probabilidad de completar su ciclo de vida. Se presenta la fenología de datos de vuelo para T. ballus a partir de la base de datos Atlamar (1 073 registros de 1887 a 2003), sobre la base de los 438 registros en que se conocen año, mes y día. Este período coincide con la floración de diversas especies de leguminosas, incluyendo las lentejas. El pico de actividad de los imagos se produce en la segunda quincena de marzo y la primera quincena de abril, y las últimas larvas deben estar presentes en el campo hasta principios de junio.

Palabras clave: Tomares ballus, Lycaenidae, lenteja, planta hospedera, plaga, Lens culinaris.

\section{REFERENCES}

Castroviejo, S. (ed.) 1999. Flora Iberica. Vol VII (I) Leguminosae (Partim). Real Jardín Botánico (CSIC), Madrid, Spain. 
Castroviejo, S. (ed.) 2000. Flora Iberica. Vol VII (II) Leguminosae (Partim). Real Jardín Botánico (CSIC), Madrid, Spain.

Castroviejo S. \& H. Pascual. 1995. Notas sobre el género Lens Mill. (Leguminosae) en la Península Ibérica e Islas Baleares. Anales Jard. Bot Madrid 53: 177-180.

Chapman, T.A. 1904. Notes towards a life-history of Thestor ballus. Entomologist's Records 26: 254-260, 276-284.

Descimon, H. 1993. Le Faux-Cuivre smaragdin, Tomares ballus F. In T. R. New (ed.): Conservation Biology of Lycaenidae (Butterflies). Occasional Paper of the IUCN Species Survival Commission No. 8. Gland, Switzerland: 95-96.

Descimon, H. \& L. Nel. 1986. Tomares ballus F.: est-il une espèce vulnèrable en France? Alexanor 14: 219-231.

Downey, J. 1987. Lycaenidae (Papilionoidea), p. 443-445. In F. W. Sterh. Inmature Insects. Kendall/Hunt, Dubuque, Iowa, USA.

FAO. 2003. Los Aspectos Económicos de la Agricultura de Conservación. Servicio de Manejo de las Tierras y de la Nutrición de las Plantas. Dirección de Fomento de Tierras y Aguas. FAO, Rome. (also available on-line: ftp://ftp.fao.org/docrep/fao/005/y2781S/y2781S00.pdf)

García-Barros, E., M.L. Munguira, J. Martín Cano, H. Romo Benito, P. García Pereira \& E.S. Maravalhas. 2004. Atlas de las mariposas diurnas de la Península Ibérica e islas Baleares (Lepidoptera: Papilionoidea \& Hesperioidea). Atlas of the butterflies of the Iberian Peninsula and Balearic Islands (Lepidoptera: Papilionoidea \& Hesperioidea). Monografías S.E.A., Zaragoza, Spain.

Gómez de Aizpurua, C. 1981. Biología y morfología de las orugas. Tomo IX. Boletín de Sanidad Vegetal. Fuera de serie, $n^{\circ} 23$. Madrid, Spain.

Jordano, D. 1987. Estudio ecológico de la relaciones entre mariposas y planta: interacciones de Tomares ballus (Lycaenidae) y Astragalus lusitanicus (Fabaceae). $\mathrm{PhD}$ Thesis. University of Córdoba. Córdoba, Spain.

Jordano, D. \& J. Rodríguez 1987. Nuevas citas de plantas nutricias para tres especies de ropalóceros. Shilap Revta. Lepid. 10: 218-223.

Jordano, D., J. Fernández Haeger \& J. Rodríguez. 1989. The life history of Tomares ballus (Fabricius, 1787) (Lepidoptera: Lycaenidae): phenology and host plant use in Southern Spain. J. Res. Lepid. 28: 112-122.
Jordano, D., J. Fernández Haeger \& J. Rodríguez. 1990. The effect of seed predation by Tomares ballus (Lepidoptera: Lycaenidae) on Astragalus lusitanicus (Fabaceae): determinants of differences among patches. Oikos. 57: 250-256.

Lafranchis, T. 2000. Les papillons de tour de France, Belgique et Luxembourg et leurs chenilles. Parthenope, Mêze.

Lockwood, M. 2006. Distribució i ecologia de Tomares ballus (Fabricius, 1787) a Catalunya (Lepidoptera: Lycaenidae). Bull. Soc. Cat. Lep. 97: 63-81.

Malicky, H. 1969. Versuch einer Analyse der Oekologischen Beziehungen zwischen Lycaeniden (Lepidoptera) und Formiciden (Hymenoptera). Tijdschrift loor Entomologie 112: 213-298.

Malicky, H. 1970. New aspects on the association between Lycaenid larvae (Lycaenids) and Ants (Formicidae, Hymenoptera). Journal of he Lepidoptrists' Society 24: 190-202.

Martín Cano, J. 1982. La biología de los Licénidos españoles. (Lep.: Rhopalocera). Miscelánea conmemorativa X aniversario U.A.M.: 1003-1020. UAM, Madrid, Spain.

Martín Cano, J. 1984. Biología comparada de Lampides boeticus (L.), Syntarucus pirithous (L.) y Polyommatus icarus (Rott.). (Lep., Lycaenidae). Graellsia XL: 163-193.

Munguira, M.L., E. García-Barros \& J. Martín Cano. 1997. Plantas nutricias de los licénidos y satirinos españoles (Lepidoptera: Lycaenidae y Nymphalidae). Boln. Asoc. esp. Ent. 21: 29-53.

Pérez Andueza, G., M. de los Mozos Pascual, E. Acebrón Linuesa \& N. Cardo Maeso. 2002. Influencia de la asociación de cultivos (leguminosa-cereal-oleaginosa) sobre las poblaciones de los principales grupos de insectos plaga y enemigos naturales del cultivo de la lenteja (Lens culinaris Medikus) en España Central. Bol. Sand. Vegl. Plagas 28: 505-514.

Pérez Andueza, G., M. de los Mozos Pacual. \& M. Portillo Rubio. 2004. Plagas clave de la lenteja (Lens culinaris Medikus) en Castilla-La Mancha (España Central): pérdidas de producción e influencia sobre los componentes del rendimiento. Bol. Sand. Veg. Plagas 30: 763-772.

Tolman, T. \& R. Lewington. 2002. Guía de las Mariposas de España y Europa. Lynx, Barcelona, Spain. 
Thomas, C.D. \& H.C. Mallorie. 1985. Rarity, species richness and conservation butterflies of the Atlas Mountains in Morocco. Biological Conservation, 33: 95-117.

Van Swaay, C. A. M. \& M.S. Warren. 1999. Red Data Book of European Butterflies (Rhopalocera). Nature and Environment, No. 99. Council of Europe, Strasbourg, France.

\section{REFERENCIAS DE INTERNET}

FAO. 2008. B79 Lens culinaris Medik. (L. esculenta Moench) (Downloaded: May 4, 2008, www.fao.org/ ag/AGA/AGAP/FRG/afris/es/Data/252.HTM)

USDA. 2008. Regulated Plant Pest List. United States Department of Agriculture. Animal and Plant Health Inspection Service, Washington, DC. (Downloaded: May 4, 2008, www.invasivespecies.org) 